\title{
Executive Privilege: The Sovereign Exception in Action
}

Edwin Kent Morris, Virginia Tech

ekmorris@vt.edu

During the summer of 2012, the House of Representatives found President Obama's Attorney General Eric Holder in contempt of Congress. Holder was charged for failing to release particular documents - "deliberative process memos" to be exact that allegedly "cover up" certain information pertaining to the flow of weapons to Mexico. Several theories have been posited by both Republicans and Democrats, some going so far as to suggest that funneling weapons to Mexico will increase border gun violence, thereby allowing the Obama administration to come down hard on second amendment rights of bearing arms. In practical politics, this seems a little excessive. Nevertheless, the story does evoke Watergate and the general question of the exercise of power within constitutional limitations of the three branches of government. At issue is really not whether Holder is in contempt, or if Congress is overstepping its boundaries, but rather if President Obama's use of "executive privilege" is warranted - the same type of privilege former President Nixon attempted to use to circumvent the release of his Oval Office recordings during Watergate.

My project is to attempt to answer these questions by providing a brief and theoretical history of the notion of executive privilege and to underscore that although Americans may pride themselves on being a democracy of laws and not men, those in politics, as within and outside the law, often find themselves in precarious situations where the powers of government are blurred and unclear, particularly in situations of 
emergency or immediate threats to the existence of the state. This could range from immanent attacks on American soil (i.e. violence and destruction) or at moments when it is necessary to suspend law in order to protect law and order, and therefore the state. At the heart of this piece, I will discuss the relationship between executive privilege and what German political theorist and legal scholar Carl Schmitt called the decision on the exception.

All states across the globe, including the United States, are grounded in what political scientists and theorists call "sovereignty." Sovereignty is the foundation upon which the authority and legitimacy of the state rests. It is the "locus and nature of the agency that constitutes a political system."1 Sovereignty is meant to designate the place where self-sufficient power is ultimately said to reside; it signifies exclusive control over a bounded territory. ${ }^{2}$ Sovereignty is the means by which politics is activated in order to give an account of the purposive and integrative, that rule which can be made to function as legitimate. ${ }^{3}$ In other words, it is through sovereignty that human beings are able to make an order that is of laws and not men - it gives weight, substance, and legitimacy to our laws. Furthermore, it provides the reason and the obligation to obey laws, as well as the authority to inflict penalties for breaking them.

The theoretical origins of sovereignty date back well before the seventeenth century, with early articulations of sovereignty explicated by French theorist Jean Bodin.

\footnotetext{
${ }^{1}$ Carl Schmitt, Political Theology, trans. George Schwab (Chicago: University of Chicago Press, 2005), xi. From the Forward by Tracy B. Strong.

${ }^{2}$ Scott G. Nelson, Sovereignty and the Limits of the Liberal Imagination (London: Routledge, 2010), 3.

${ }^{3}$ Nelson, Sovereignty and the Limits of the Liberal Imagination, 6-18.
} 
Most Americans are probably more familiar with Thomas Hobbes' Leviathan, written during the English civil wars of the seventeenth century. Thinkers of the period began to question the nature of what holds society together; what could be orchestrated in order to establish the legitimacy of the state, society, of ruler and ruled? It is precisely legitimacy and the order of the state that sovereignty was envisioned to create. In Leviathan, Hobbes laid the foundation for numerous contrivances that would forever become part of the canon of political theory, yet have transcended theory to actual application and practice that still resonates, shapes, and guides our politics today. His main contribution is the rationale for humans coming together under a social contract in order to leave the state of nature and live in a civil society.

Hobbes theorized that before political society, human life existed in a "state of nature," often described as both a state of perfect freedom but also a state of political nothingness. "The state of nature symbolized not only an extreme disorder in human relations, causing men to consent to the creation of an irresistible power; it was also a condition distraught by an anarchy of meanings. Each man could freely use his reason to seek his own ends: each was the final judge of what constituted rationality." ${ }^{4}$ Hobbes believed in the state of nature human life existed in bellum omnium contra omnes (i.e., a war of all against all). In Leviathan's most infamous quote, life in the state of nature would be "nasty, brutish, and short." Each individual possessed the means to do what they desired based on a general equality of mental and physical capabilities. For

\footnotetext{
${ }^{4}$ Sheldon S. Wolin, Politics and Vision: Continuity and Innovation in Western Political Thought (New Jersey: Princeton University Press, 2004), 230.

${ }^{5}$ Thomas Hobbes, Leviathan (New York: Barnes \& Noble, 2004).
} 
Hobbes, it was precisely this perfect freedom and equality that led individuals to be in a constant state of war with one another. Coming together upon a covenant or "social contract," and establishing a "commonwealth," (i.e. state) individuals would give up part of their own individual sovereignty (which implies our sense of autonomy and agency) and unlimited freedom in the state of nature to essentially become restrained in a new civic order, but at the same time secure our possessions and property. Hobbes borrowed significantly from Bodin's "absolutist" conception of sovereignty: "the absolute

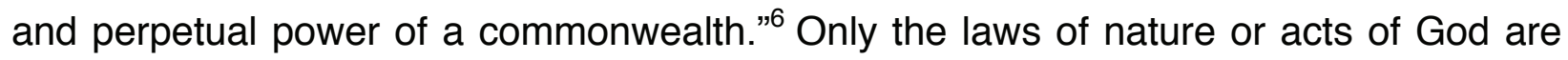
above the sovereign; and hence, only the sovereign would have the power to enforce the covenant in order for it to be effective.

Although Hobbes intended the sovereign to be like a monarch, the sovereign today is not limited to power in the hands of one individual. Rather, the notion of sovereign can be taken to mean either an individual or, more commonly, a body of officials like a Congress or Parliament. For our purposes, let us simply think of the President of the United States as the sovereign. What is difficult practically, juridically, and theoretically in the United States is the shared and divided powers of the government, for instance, bicameral legislature. By the standards of the U.S. Constitution, Congress's powers as the legislative body should trump the president's executive powers or duties, say for instance, in declaring war. Only Congress has the power to declare war only after the president recommends or asks them to do so. Yet as

\footnotetext{
${ }^{6}$ Jean Bodin, On Sovereignty (New York: Cambridge University Press, 2008), 1.
} 
we have seen in recent years, Congress time after time has ceded greater authority to the executive, particularly in terms of the president unilaterally declaring war (with Congress giving approval only after the fact).

John Locke's contributions to politics are many, particularly his views on natural rights, consent of the people in establishing government, society predicated on freedom and liberty, and most importantly, private property. For him, "The great and chief end therefore, of men uniting in commonwealths and putting themselves under government is the preservation of their property..." ${ }^{7} \mathrm{He}$ advanced these ideas through a reconceived state of nature and social contract, introducing in the process the prototypes of constitutional government that provides the basic fundamentals of the U.S. democratic republic. In his Second Treatise of Government, Locke comes to his discussion of what he calls "prerogative." According to Locke, "For since in some governments the law making power is not always in being, and is usually too numerous, and so too slow...on all occasions and upon all persons that may come in their way, therefore there is a latitude left to the Executive power to do many things of choice, which the laws do not prescribe..." ${ }^{8}$ Locke is not entirely clear as to when, if, or how this prerogative is to be applied. He merely makes the case that prerogative is necessary when the laws are not clear or do not exist. Locke does not envision this ability to be used arbitrarily, say for political purposes as Nixon tried to do, and perhaps as President Obama has done. Locke's prerogative, however vague, appears to be warranted only to expedite

\footnotetext{
7 John Locke, Two Treatises of Government (New York: Cambridge University Press, 2008), 350-351.

${ }^{8}$ Locke, Two Treatises of Government, 374.
} 
governmental matters of great importance when issues could not be taken care of under normal circumstances, times of great confusion, or in our terms today, security dilemmas in which decisive decisions had to be made regarding the law or security threats to the state. But there is more to it.

Carl Schmitt's Political Theology concerns these "prerogatives" of the sovereign as the concept has developed in the West, but theoretically goes deeper than that. Schmitt declares, famously, that "Sovereign is he who decides the exception." ${ }^{\text {Th }}$ This definition is aimed at defining sovereignty towards a theory of the state in the juridical sense, providing a point of reference used in his later work. First, what does he mean by exception? "The exception...can at best be characterized as a case of extreme peril, a danger to the existence of the state, or the like." ${ }^{\prime 10}$ The exception for Schmitt is an immediate, existential threat to the state (e.g. nuclear warhead heading towards a densely populated city). Therefore, the sovereign 'steps up' and calls the exception. Essentially, the sovereign decides what the exception is and how to solve it, whenever or whatever that crisis or situation may be. The precondition(s) for the decision on the exception are unlimited since these conditions cannot be codified into preformed law since that would limit the sovereign in making (the) decision(s). Schmitt disagreed with the limits constitutions, for example, the U.S. Constitution, imposed on the decision. Schmitt states, "the most guidance the constitution can provide is to indicate who can act in such a case. If such action is not subject to control, if it is not hampered in some

\footnotetext{
${ }^{9}$ Schmitt, Political Theology, 5. Italics added for emphasis.

${ }^{10}$ Schmitt, Political Theology, 6.
} 
way by checks and balances, as is the case in a liberal constitution, then it is clear who the sovereign is." ${ }^{11}$ The latter part of this quote is telling, as Schmitt appears to be uncertain of just "who the sovereign is." From Hobbes to Rousseau, the question of who, precisely, is the sovereign still appears in the $20^{\text {th }}$ century for Schmitt, a question left unanswered by liberal democratic forms of government throughout Europe and the West. It is clear that Schmitt sides with Hobbes since it is an individual "he" that decides on the exception. However, if Schmitt were to have had his hand in the development of a constitution, some might suggest Schmitt would side with Rousseau. ${ }^{12}$

More importantly, Schmitt brings attention to the paradox of sovereignty in stating "although he stands outside the normally valid legal system, he nevertheless belongs to it, for it is he who must decide whether the constitution needs to be suspended in its entirety." ${ }^{13}$ In other words, the sovereign is simultaneously the source of authority and legitimacy for law, yet at the same time is under and over it. For the most part, our lawmakers obey laws. Yet when it comes to that exceptional case, situation, or what not, the sovereign can suspend the laws they have created, essentially making them, for Schmitt, above and beyond the law at all times: inside and outside. On the one hand, Schmitt's decision on the exception generally means the decision to suspend law in order to save law by stopping the impending dissolution of the state. If a danger is so great and immediate, constitutional limitations such as Congress having the power to

\footnotetext{
${ }^{11}$ Schmitt, Political Theology, 7.

${ }^{12}$ Edwin Kent Morris, Liberal Democracy and The Political: A Comparison of Carl Schmitt and Sheldon Wolin (Master's Thesis in Political Science). Available through Virginia Tech Libraries.

${ }^{13}$ Schmitt, Political Theology, 7. Italics added for emphasis.
} 
declare war formally may be too slow, and thus the sovereign - presumably the president - can call upon this power of exception and make decisions to save the state from annihilation. To be sure, by Schmitt's standards, the sovereign ought to announce when the exception is effectively over and that the suspension of law has been lifted. On the other hand, sovereignty is not limited to making this decision only. Recall above that for Hobbes sovereignty's initial purpose is the foundation of the state, and therefore, law and order. Schmitt clearly states that "the exception is to be understood to refer to a general concept in the theory of the state, and not merely to a construct applied to any emergency decree or state of siege," ${ }^{14}$ implying there is something much more important going on legally and theoretically than merely the decision to decide if the exception is at hand and how to solve it.

Contemporary political theorist Giorgio Agamben suggests "at issue in the sovereign exception is... the creation and definition of the very space in which the juridical-political order can have validity... The sovereign decides... the normal structuring of life relations, which the law needs... In this sense, the exception is the originary form of law. ${ }^{15}$ If the state of nature is merely the absence of government, then what is truly exceptional from the beginning is the foundation and demarcation of manmade, artificially constructed government and law. It would seem that for both Schmitt and Agamben the exception constitutes the very origin of modern politics. The implications of this are profound, but the limitations of this piece prevent me from

\footnotetext{
${ }^{14}$ Schmitt, Political Theology, 5.

${ }^{15}$ Giorgio Agamben, Homo Sacer: Sovereign Power and Bare Life (Stanford: Stanford University Press, 1998), 17-26. Italics added for emphasis.
} 
elucidating further on this particular point. In any case, the sovereign exception remains to this day a form of unrestrained power outside the law and yet absolutely necessary for the authority and legitimacy of law - a source to "tap in to," so to speak, in the form of executive privilege for whatever reason or whenever circumstance demands it. As President Nixon once said, "When the president does it, it is not illegal." It is a power source so great that presidents ought to be cautious about using it. Yet, presidents of the United States have been evoking this 'privilege' for both legitimate and not-so legitimate reasons since, roughly, the founding itself. And now we have seen President Obama use this power for the first and only time during his administration. What is at stake for the president in the Holder case?

Abraham Lincoln was the first president to use the exceptional powers of the Executive Branch with the outbreak of the Civil War. One could say that Lincoln acted as an absolute dictator from April $15^{\text {th }}, 1861$, when he called for an army counter to the constitution, until July $4^{\text {th }} 1861$, when he convened a special session of Congress for them to officially declare war. ${ }^{16}$ Furthermore, with the Emancipation Proclamation in 1862, "the president proclaimed the emancipation of slaves on his authority alone."17 Using executive privilege, he unilaterally went over Congress and binding laws that were in effect across the United States regarding slavery, including the three-fifths rule in the Constitution. His suspension of habeas corpus two days later towards southern rebels perhaps can be said to demonstrate the suspension of law during an exceptional

${ }^{16}$ Giorgio Agamben, State of Exception, trans. Kevin Attell (Chicago: University of Chicago Press, 2003), 20.

${ }^{17}$ Agamben, State of Exception, 21. 
or emergency crisis. After Lincoln, the president of the United States appeared to wield the sovereign decision on the exception as posited by Schmitt.

President Woodrow Wilson would later assume broader powers utilizing the new apparatus of power Lincoln established for the executive branch. The difference, however, (and I should add probably because Wilson was a political scientist) between Wilson and Lincoln is that Wilson asked Congress to give him the authority to meet certain objectives. Rather than declaring a state of exception unilaterally as Lincoln did, Wilson used his power to push for exceptional laws, laws today that would seem contrarian to our widely held freedoms of speech and protest. In fact, Wilson basically eliminated civil liberties all together for an extended period of time. ${ }^{18}$ President Franklin Delano Roosevelt also used the exceptional powers of the executive in order to combat the Great Depression. Often in $20^{\text {th }}$ century American history, the term "war" is used metaphorically in a variety of ways when what is at issue politically is of great importance to the country or the administration in power. For example, the war on poverty, war on drugs, and war on terror (as well as the war on Christmas). This was not mere word play -Roosevelt, literally, "declared war" on the Great Depression. Making his case to the American people who were suffering, Roosevelt used his executive privilege to enact the numerous legislation that we now refer to as the New

\footnotetext{
${ }^{18}$ Agamben, State of Exception, 21. Agamben states: "From 1917 to 1918, Congress approved a series of acts (from the Espionage Act of June 1917 to the Overman Act of May 1918) that granted the president complete control over the administration of the country and not only prohibited disloyal activities (such as collaboration with the enemy and the diffusion of false reports) but even made it a crime to 'willfully utter, print, write, or publish any disloyal, profane, scurrilous, or abusive language about the form of government of the United States.' "
} 
Deal. For example, the series of statutes issued that culminated in the National Recovery Act of June $16^{\text {th }}, 1933$ effectively gave FDR "an unlimited power to regulate and control every aspect of the economic life of the country - a fact that is in perfect conformity with the already mentioned parallelism between military and economic emergencies that characterizes the politics of the twentieth century." ${ }^{19}$ President Roosevelt's actions taken throughout World War II extended these powers for a variety of purposes, but perhaps most disconcerting was his violation of civil rights with the internment of Japanese American citizens in early 1942 in the name of national security.

In any case, it was President Richard Nixon and what some political scientists call the rise of the "Imperial Presidency" that made heightened public and scholarly awareness of prerogative, exception, and executive privilege. When Nixon came into office, he claimed his administration would offer a "New Federalism" in vein of the New Deal, New Frontier, and Great Society that came before. Nixon seemed intent on applying conservative principles to the sweeping Democratic Party social entitlement programs and, more generally, to the role of the federal government in the domestic sphere. Faced with a Democratic majority in Congress, many of his conservative redefinitions of federal responsibilities were never enacted. Nixon, considering the type of person he would later be revealed to be, decided that most domestic policy is actually generated by proposals and, as the founders put it, the "energy" of the president. What this meant was that Nixon saw the executive branch both as more powerful than the

\footnotetext{
${ }^{19}$ Agamben, State of Exception, 22.
} 
legislative branch in terms of enacting policy and making laws, and, more importantly, that the responsibilities of government could emanate from the White House rather than Congress. This is, of course, in complete contradiction to the U.S. Constitution. Among the uses of executive power, Nixon enlarged the Executive Office of the President (EOP), creating a number of new offices and departments directly accountable to the president including the Domestic Council, the Office of Management and Budget (OMB), and the formation of "White House consultants," all of which trumped the traditional powers and roles of presidential cabinet officers. Paradoxically, a conservative president increased the size of the federal government institution of the executive branch in both areas of domestic and foreign policy.

From Truman to Nixon, followed by Ford and Carter, and the Reagan Revolution in 1980, the Cold War was in the background of U.S. foreign policy. As Pease suggests, "After World War II, America became a state of exception." ${ }^{20}$ But what does this mean exactly? Let's back up a moment and provide some insight into the Cold War. Of course, this was not a traditional war by any means. The United States and the U.S.S.R competed with one another for global hegemony in both politics and economics. Although the U.S. and the Soviets never engaged one another on the battlefield, the United States took great effort to stymie or "contain" the spread of communism in both Korea and Vietnam - the "domino theory" that if one country falls to communism, then several more will follow. Hence the reason for those respective wars. Herein lies the

${ }^{20}$ Donald E. Pease, The New American Exceptionalism (Minneapolis: University of Minnesota Press, 2009), 62. 
nature of the permanent state of exception, alongside other dubious and questionable considerations of and by the United State government. If the Cold War is "war," then juridically and theoretically, then the president would wield the awesome power of exception at all times. After the Cold War and the collapse of the Soviet Union in 1991, it was not long after that President George H.W. Bush found 'new enemies' in the Middle East; thus our interests in engaging in the Gulf War. There is a pattern here: Ever since post-1945, the United States military has been involved somewhere, globally, usually in the form of warfare. Put crudely, if war never ends, then neither does the exception, and thus it becomes, perhaps, permanent.

In recent years, President George W. Bush faced a number of criticisms regarding executive privilege and the decision on the exception after the September $11^{\text {th }}$, 2001 terrorists attacks. Rather than being a temporary suspension of the legal order in efforts to preserve the state in the face of existential dissolution or annihilation, the exception perhaps has become permanent in the absence of a legitimate enemy (i.e. the concept of terror is not a traditional sovereign state but is rather an idea that can occur anywhere at anytime). To reiterate, since 1945, the United States has been almost perpetually involved in conflicts or wars over seas, making the notion of war powers a permanent part of the president's abilities. This leads to both practical and theoretical questions of where the president's power effectively begins and ends. The changing ideological scope of the Supreme Court of the United States seems to have conferred additional powers through the Executive Vesting Clause (see below) in light of 
9/11. Together, the subject of sovereignty and executive privilege suggest an indistinction or blurring of the lines between law, order and chaos, no sense of inside/outside the law, and the creation of space(s) where law, I suggest, becomes meaningless.

These examples speak to a number of aspects taken for granted by political scientists and theorists that are not well known outside of students of American politics and theory. First of all, once presidents establish extra-constitutional powers, presidents that follow them never give up that power up. These new "powers" become institutionalized in the Office of the Presidency and, to be sure, have historically been used again and again, as understood in the examples above. Second, as dictated by the U.S. Constitution, Article II invests the executive with duties, responsibilities and powers that go beyond Commander-in-Chief. Called the Executive Vesting Clause, it implies that the president enjoys a number of powers traditionally invested with executives (i.e. the executive power). Although it is mostly concerned with foreign affairs and the execution of laws, the vesting clause may grant authority beyond these areas. ${ }^{21}$ Just as Locke thought reasonable that executives should have prerogatives, many people believe that the clause supports the notion of executive privilege that is at question here. Furthermore, the vesting clause is suggested to give the president certain immunities in the court of law, but also gives the president the emergency powers that relate back to the discussion of the exception. Despite Supreme Court

\footnotetext{
${ }^{21}$ Edwin Meese III, et al, The Heritage Guide to The Constitution (Washington D.C.: Regenery Publishing
} Inc, 2005), 181. 
decisions that have theoretically and juridically limited the scope of these powers, they do not eliminate them or set up boundaries for their application. Their decisions on the president's use of these powers have always been limited to the situation at hand in terms of the constitutionality of the president's use of that authority - hence the court's 1974 decision in United States v. Nixon - not whether or not it exists or can be authorized. Despite the Nixon ruling that famously declared the president is not above the law, it appears that was meant only for that particular situation. If that were the case, then why do presidents continually make decisions citing, essentially, their sovereign authority without Supreme Court repercussions? The 1926 Supreme court case Myers v. United States arguably solidified the Executive Vesting Clause as the source for numerous, and perhaps, arcane powers at the president's exposal - including the use of executive privilege to not release particular documents as is the case with Eric Holder being found in contempt of Congress.

Is President Obama correct to cite executive privilege in order to withhold these "deliberative process memos" that Attorney General Eric Holder has been found in contempt of Congress for not producing? My answer would be yes and no. To the former, as I hope to have made clear, the president now wields a host of powers that seemingly go against the U.S. Constitution, granting him broad authority and abilities in a number of areas, both domestically and internationally. Yet, as the Nixon case exemplifies as well as the historic events when the executive has made use of their sovereign powers, this situation regarding the release of these memos seems rather 
arbitrary and promotes a number of conspiracy theories the incumbent-president in an election year does not need on his plate. If anything, perhaps, the president using executive privilege in this case has only made matters worse, considering the situation in which he has issued it. Furthermore, when previous presidents (albeit, Nixon) have cited this authority, it has generally been in times of war, turmoil, or strife contingent to the existence of the state; therefore, it is reasonable to assume these presidents did the right thing in using their emergency powers or executive privilege (for the most part). Moreover is the use of executive privilege in a state of exception that is perhaps permanent. The War on Terror appears to be never-ending, just like the war on drugs and poverty. They may not make the evening news every night, but these 'wars' are still there in the background, just as American soldiers are still in Afghanistan and Iraq. If this is the case, then it logically follows that President Obama has at his fingertips extraordinary executive powers due to the state of exception being at hand - a constant variable in the background where law is theoretically suspended to take care of things pertaining to the war on terror while law remains for us citizens to follow living in the domestic polity. Once again, the use of executive privilege, just like the blurring and indistinction spoken about of above, remains just that: blurred. President Obama's use of executive privilege cannot be weighed on any solid conventions because theoretically he is the sovereign making a decision within an exceptional and never-ending crisis, even if that decision is made towards a situation dealing with the disclosure of documents. 
In conclusion, President Obama does appear warranted in his use of executive privilege, despite Congress finding his Attorney General in contempt of court for not disclosing these documents. Questions remain in that case however. If these documents were so important, why did the President not issue this order earlier? Are these documents vital to U.S. national security, or, more cynically, would these documents be damaging to the President's re-election this November, in vein of the White House tapes Nixon tried desperately to conceal before being forced to give them up to the Supreme Court and subsequently resigning from the presidency? I do not have answers to these questions, merely speculations. Nevertheless, I hope this discussion of the theoretical and yet practical aspects of executive privilege and sovereign authority has been enlightening. Despite the predominant relationship the decision on the exception has to foreign affairs, political and social arrangements within states often affect that state's decision-making process in relation to other states. What a state does internationally reciprocates in a number of ways back to the domestic life of citizens and the quality of life and experience of politics a given polity. ${ }^{22}$ Therefore, executive privilege and exception go hand in hand, I suggest, to both domestic and international concerns. It may seem trite to suggest that President Obama's use of executive privilege reaches the extent of the sovereign exception, particularly as I have laid out in this piece. However, it should be clear that just because such magnitude is not present in the immediate moment of this political story does not mean the use of this authority is

\footnotetext{
${ }^{22}$ Cynthia Weber, International Relations Theory: A Critical Introduction - Third Edition (New York: Routledge, 2010), 41, 61-81.
} 
any less greater or warranted than when pertaining to war. Between the three branches of government in the United States, this question of situational authority is precisely a point Carl Schmitt was trying to convey over 80 years ago: who decides? It appears with the increases in executive power over the last several decades, apparently President Obama believes he decides, just as President George W. Bush was "the decider." Thus, the exception remains. 